\title{
Spatial variability of water use efficiency in China's terrestrial ecosystems
}

\author{
Xian-Jin Zhu ${ }^{\text {a }}$, Gui-Rui Yu ${ }^{\text {a, } *}$, Qiu-Feng Wang ${ }^{a}$, Zhong-Min $\mathrm{Hu}^{\text {a }}$, Han Zheng ${ }^{\text {a,b }}$, Sheng-Gong Li $^{\text {a }}$, \\ Xiao-Min Sun ${ }^{\mathrm{a}}$, Yi-Ping Zhang ${ }^{\mathrm{c}}$, Jun-Hua Yan ${ }^{\mathrm{d}}$, Hui-Min Wang ${ }^{\mathrm{a}}$, Feng-Hua Zhao a, Jun-Hui Zhang ${ }^{\mathrm{e}}$, Pei-Li Shi ${ }^{\mathrm{a}}$, \\ Ying-Nian Li $^{f}$, Liang Zhao ${ }^{f}$, Fa-Wei Zhang ${ }^{f}$, Yan-Bin Hao ${ }^{b}$

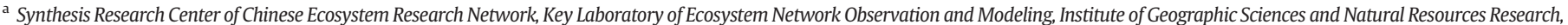 \\ Chinese Academy of Sciences, Beijing 100101, China \\ b University of Chinese Academy of Sciences, Beijing 100049, China \\ c Key Lab of Tropical Forest Ecology, Xishuangbanna Tropical Botanical Garden, Chinese Academy of Sciences, Menglun 666303, China \\ d South China Botanical Garden, Chinese Academy of Sciences, Guangzhou 510650, China \\ e Institute of Applied Ecology, Chinese Academy of Sciences, Shenyang 110016, China \\ ${ }^{\mathrm{f}}$ Northwest Institute of Plateau Biology, Chinese Academy of Sciences, Xining 810001, China
}

\section{A R T I C L E I N F O}

Article history:

Received 25 July 2014

Received in revised form 10 February 2015

Accepted 11 March 2015

Available online 14 March 2015

\section{Keywords:}

eddy covariance

water use efficiency

terrestrial ecosystems

ChinaFLUX

spatial pattern

altitude

leaf area index

vertical variation

\begin{abstract}
A B S T R A C T
Water use efficiency (WUE) reflects the coupling of carbon and water cycles. Analyzing the spatial variability of WUE can improve our understanding on the interaction between carbon and water cycles at a large scale, which also provides a basis for improving the regional carbon budget assessment. Based on China's eddy covariance measurements, we examined the spatial variation of China's WUE and its affecting factors. WUE showed a decreasing trend with the increasing altitude, which was the result of ecosystem type distribution resulting from the climatic gradient. After fully considering the vertical variation of WUE, we found that not only mean annual air temperature (MAT), mean annual precipitation (MAP), and mean leaf area index (MLAI) but also mean annual total photosynthesis active radiation (MAR) affected the spatial variation of WUE. With the increasing MAT, MAP, and MLAI, WUE increased significantly but the increasing MAR decreased WUE. The spatial variation of WUE could be directly depicted by MLAI and altitude, the equation including which explained 65\% of the spatial variation of WUE. The effects of MAT and MAP on the spatial variation of WUE may be achieved through altering MLAI, while the mechanism underlying the effect of MAR on the spatial variation of WUE was still unclear, which should be the subject of future investigations. This study reveals the vertical variation of WUE and provides a new approach to generate the spatial variation in WUE, which will benefit the regional carbon budget assessment.
\end{abstract}

(c) 2015 Elsevier B.V. All rights reserved.

\section{Introduction}

Considerable attention in ecological studies is being given (Finzi et al., 2011; Schlesinger et al., 2011; Wang et al., 2012) to the close coupling of carbon and water cycles, which reflects the interaction between carbon and water cycles. The coupling between carbon and water cycles can be represented by the term "water use efficiency (WUE)", which is often defined as the ratio of productivity to water loss (Reichstein et al., 2002; Beer et al., 2007; Steduto et al., 2007; Zhao et al., 2007). Analyzing the spatial variability of WUE is helpful for understanding the interaction between carbon and water cycles at a large scale (Ito and Inatomi, 2012), which may provide an alternative

\footnotetext{
* Corresponding author at: Institute of Geographic Sciences and Natural Resources Research, Chinese Academy of Sciences, 11A Datun Road, Chaoyang District, Beijing 100101, China. Tel./fax: + 861064889432.

E-mail address: yugr@igsnrr.ac.cn (G.-R. Yu).
}

approach for regional carbon budget assessment (Beer et al., 2007, 2009, 2010).

Based on network eddy covariance measurements, which can simultaneously measure $\mathrm{CO}_{2}$ and $\mathrm{H}_{2} \mathrm{O}$ fluxes, scientists have analyzed the spatial variability of WUE in China and other regions. For example, using measurements from three forests in the North-south Transect of East-China (NSTEC), Yu et al. (2008) analyzed the difference in WUE among forests and found that WUE increased with increasing latitude, which resulted from the decreasing mean annual air temperature (MAT) and precipitation (MAP). Using observations from Northern China and Southeast China, Xiao et al. (2013) found that the spatial variability of WUE was primarily associated with MAP. Using measurements in three grasslands in the China Grassland Transect (CGT), Hu et al. (2008) found that WUE increased with the increasing leaf area index (LAI) but was not related to the increasing MAT and MAP. Integrating global measurements covering 43 sites, Beer et al. (2009) investigated the spatial variation of inherent water use efficiency (IWUE), the product of WUE multiplying vapor pressure deficit, and 
found that LAI dominated the spatial variation in IWUE. However, most of previous studies were conducted within the same ecosystem type (Hu et al., 2008) and covering limited range in altitude among ecosystems (Xiao et al., 2013), which made little attention paid to the vertical variation of WUE, while there was a substantial difference in global altitude. Therefore, it was still unclear whether WUE exhibited a vertical variation. In addition, if there was a vertical variation in WUE, we were still unknown about whether factors affecting the spatial variation of WUE varied after fully considering its vertical variation, which made our current understanding on the spatial variation of WUE imprecise.

Because of the uplift of the Qinghai-Tibetan Plateau (Wu et al., 2007), China experiences a distinct climate and ecosystem gradient that exhibits not only a horizontal distribution but also a notable vertical distribution (Yu et al., 2006). The unique distribution of climate and ecosystems in China provides a valuable platform for analyzing the spatial variation of WUE especially its vertical variation and its affecting factors, which may be helpful for fully understanding the spatial variability of WUE in China and globally. Scientists in China has conducted eddy covariance measurements for many years (Yu et al., 2013), which made it possible to investigate the spatial variation of WUE in China.

Integrating ChinaFLUX measurements and published data in literatures, we constructed a dataset containing concurrent $\mathrm{CO}_{2}$ and $\mathrm{H}_{2} \mathrm{O}$ flux measurements from 37 sites in China (Fig. 1), investigated the spatial variation of WUE and revealed its affecting factors. The main objectives were to fully reveal the spatial variation of WUE especially its vertical variation and to clarify factors that directly affected the spatial variation of WUE in China. Our results may improve our understanding on the interaction between carbon and water cycles at a large scale and may provide an alternative approach for assessing the spatial distribution of WUE thus carbon fluxes.

\section{Material and methods}

\subsection{Sites used in this study}

In this study, we collected data from two sources: ChinaFLUX measurements and published data from the literature.
Since 2002, ChinaFLUX has conducted continuous $\mathrm{CO}_{2}$ and $\mathrm{H}_{2} \mathrm{O}$ flux measurements at 9 sites using the open path eddy covariance system (Yu et al., 2006), which covered 4 forests, 3 grasslands, 1 cropland, and 1 wetland (Fig. 1 red sites).

In addition to ChinaFLUX measurements, we also collected published data in China from the literature, which comprised a dataset covering 9 forests, 9 grasslands, 4 croplands, and 6 wetlands (Fig. 1 black sites). Sites were selected following the follow criteria. First, measurements must have been made using the eddy covariance technique. Second, measurements must have been conducted for at least 1 year and the annual total GPP and ET had to be available. Third, the annual total GPP and ET must have been collected in the same year.

After integrating ChinaFLUX measurements and data from the literature, we constructed a dataset that contained simultaneous annual total GPP and ET measurements at 37 sites. Our dataset included 13 forest sites, 12 grassland sites, 7 wetland sites, and 5 cropland sites, which together represented most of major ecosystem types (Fig. 1) in China.

\subsection{ChinaFLUX measurements and flux data processing}

ChinaFLUX measurements were conducted using the open path eddy covariance system (Yu et al., 2006), which collected the raw data at a frequency of $10 \mathrm{~Hz}$. The $\mathrm{CO}_{2}$ and $\mathrm{H}_{2} \mathrm{O}$ fluxes were calculated and stored at 30 min interval. Standard meteorological variables, including net radiation $\left(R_{n}\right)$, photosynthesis active radiation (PAR), air temperature (Ta), soil temperature (Ts), precipitation, and soil water content, were also collected simultaneously at each site (Yu et al., 2006). Energy closure exceeded 0.7 at all sites (Li et al., 2005), which indicates the reliability of ChinaFLUX measurements.

ChinaFLUX measurements were processed using traditional data quality controlling routes (Yu et al., 2006), including the threedimensional rotation (Aubinet et al., 2000), the WPL correction (Webb et al., 1980), the canopy storage calculation, and the spurious data removal. Spurious data that were caused by rainfall, water condensation or system failure, and that were lower than the friction velocity $\left(\mathrm{u}^{*}\right)$ threshold, which was calculated following Reichstein et al. (2005), were removed.

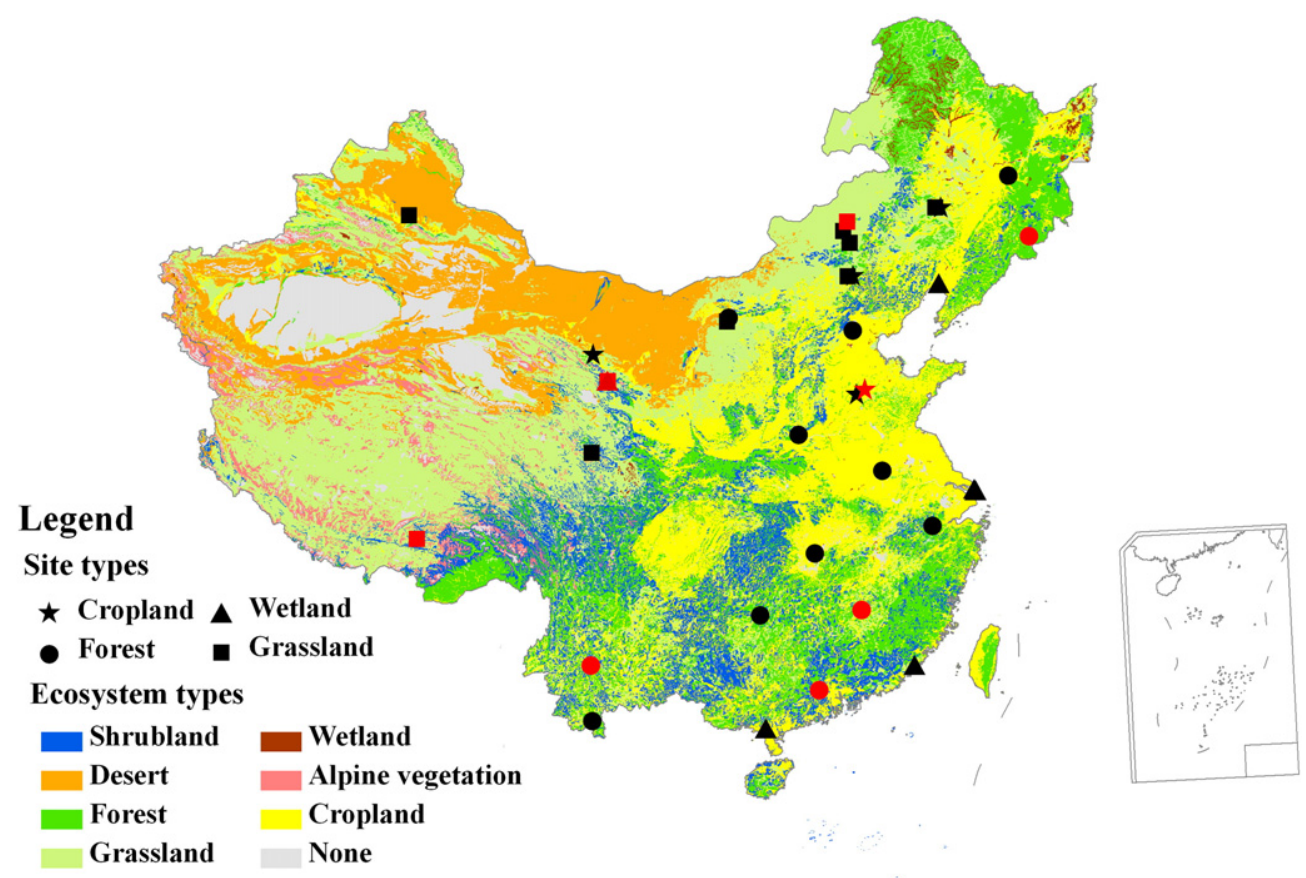

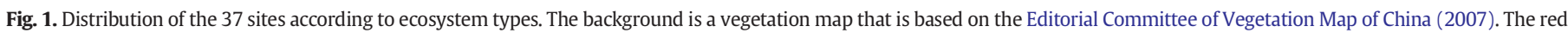
sites are ChinaFLUX sites while the black sites are other sites collected from literatures. The map was generated using ArcGIS 10.0 software. 
For $\mathrm{CO}_{2}$ fluxes, the nighttime gaps were filled using the Lloyd-Taylor equation based on Ts and daytime gaps were filled with the MichaelisMenten equation based on PAR (Falge et al., 2001b; Reichstein et al., 2005). Then, the nighttime-based approach was used to partition $\mathrm{CO}_{2}$ fluxes into GPP and ecosystem respiration (ER) (Reichstein et al., 2005; Gao et al., 2014). For $\mathrm{H}_{2} \mathrm{O}$ fluxes, data gaps for latent heat fluxes were filled using the Look-Up Tables based on Ta, vapor pressure deficit (VPD), and $\mathrm{R}_{\mathrm{n}}$ (Falge et al., 2001a; Reichstein et al., 2005), and latent heat fluxes were then regarded as ET (Hossen et al., 2012).

After data quality control, gap filling, and flux partitioning, full time series data were constructed. The annual total GPP and ET were then calculated based on data for the whole year.

\subsection{Calculations of WUE and environmental factors}

In this study, WUE was defined as the ratio of annual total GPP to annual total ET. WUE at each site-year were therefore calculated based on annual total GPP and ET.

Major climatic factors, including MAT and MAP were collected for the measurement period. If a site had missing climatic data, multiyear average climatic data were used. Mean annual total PAR (MAR) for each site during the measuring period was extracted from the interpolated PAR, which was obtained using the ANUSPLIN software with the observed PAR (Zhu et al., 2010). Geographical factors, including latitude, longitude, and altitude, were also recorded when collecting the flux data.

To facilitate the effect of LAI on the spatial variation of WUE, we explored mean annual leaf area index (MLAI) using the uniform validated MODIS LAI (Liu et al., 2012) at an 8-day temporal resolution to control for variation in LAI measurements.

In addition, if sites had multi-year measurements, averages of WUE and environmental factors were therefore used as we intended to analyze the spatial variability of WUE. Therefore, the effect of unequal measurements at different sites on the spatial variation of WUE would be avoided.

\subsection{Uncertainty analysis}

There were some uncertainties in annual total GPP and ET because of errors caused by eddy covariance measurements (Baldocchi et al., 2001), different data processing routes (Falge et al., 2001b), and interannual variations (Yan et al., 2013; Xu et al., 2014). The overall relative deviation of annual total GPP that was caused by spike detection, determination of $\mathrm{u}^{*}$, and gap-filling model selection was between $3.88 \%$ and $11.41 \%$ (Liu et al., 2010), while that of annual total ET caused by different gap-filling approaches was approximately $10 \%$ (Falge et al., 2001a).

Various data processing routes resulting from different data sources such as ChinaFLUX measurements and published data may affect the spatial pattern of WUE. Data collected from different years may also affect the spatial pattern of WUE. We used Monte Carlo simulation method following Reichstein et al. (2007) to test for these effects. First, to make our analysis more conservative, a $\pm 20 \%$ relative deviation, which guaranteed random and independent error, was added to the annual total GPP and ET for each site and each year. Second, the deviation-added WUE (WUE ${ }_{\mathrm{e}}$ ) for each site-year was calculated based on the deviation-added annual total GPP and ET after setting the deviation. Third, the collected and the deviation-added WUE for each site were calculated based on the site-year WUE. Fourth, the relationships between WUE and the deviation-added WUE $\left(\mathrm{WUE}_{\mathrm{e}}\right)$ were conducted using the regression analysis and paired-sample $T$-test. Then the frequency distributions of the slope (from the regression analysis) and $\mathrm{t}$-value (from the paired-sample T-test) were obtained after conducting these simulations 500 times (Supplementary Fig. 1). If the regression slope of WUE against the deviation-added WUE $\left(W_{U} E_{e}\right)$ tended to be 1 or the paired-sample $T$-test revealed no significant difference between
WUE and the deviation-added WUE (WUE ${ }_{\mathrm{e}}$ ), the deviation of GPP and ET caused by different data processing routes and years could be considered to have little effect on the spatial pattern of WUE.

The results suggest that all regressions had high $R^{2}$ values and most slopes fell in the range of 0.95 to 1.1 (Supplementary Figure. 1a). Most t-values fell in the range of -2.03 to 2.03 (Supplementary Figure. 1b), which indicates that the difference between WUE and the deviationadded WUE was not significant. Therefore, we can conservatively conclude that the difference among various data sources and years had a negligible effect on the determination of the spatial pattern of WUE and therefore on its affecting factors.

\subsection{Statistical analyses}

Flux data from the ChinaFLUX sites were processed with MATLAB software (MathWorks Inc., Natick, MA, USA). Using the MATLAB 7.7, a one-way analysis of variance (ANOVA1) was used to test for the significance of differences in WUE among ecosystem types. The significance level was set at $\alpha=0.05$. The linear regression and nonlinear regression were used to evaluate the relationships between WUE and latitude, longitude, altitude, MAT, MAP, MAR, and MLAI. The path-analysis was conducted to assess the direct or indirect factors describing the spatial variations of WUE.

\section{Results}

\subsection{Measures of WUE in ecosystem types}

We analyzed measures of WUE in typical ecosystems and ecosystem types using our dataset (Supplementary Table 1).

WUE varied among ecosystems (Supplementary Table 1 ), ranging between 0.36 and $3.89 \mathrm{gC} \mathrm{kg}^{-1} \mathrm{H}_{2} \mathrm{O}$, with a mean of $1.72 \pm 0.91 \mathrm{gC} \mathrm{kg}^{-1-}$ $\mathrm{H}_{2} \mathrm{O}$ across the 37 sites.

The difference in WUE was also significant among ecosystem types $(F=9.93, p<0.01)$ (Fig. 2a). Forests had the highest WUE, with a value of $2.28 \mathrm{gC} \mathrm{kg}^{-1} \mathrm{H}_{2} \mathrm{O}$. Croplands had the second highest WUE (2.03 $\mathrm{gC} \mathrm{kg}^{-1} \mathrm{H}_{2} \mathrm{O}$ ), and wetlands had the third highest (1.94 $\mathrm{gC} \mathrm{kg}^{-1} \mathrm{H}_{2} \mathrm{O}$ ). Croplands and wetlands were comparable to forests, and each of these three ecosystem types was significant greater than grasslands $\left(0.84 \mathrm{gC} \mathrm{kg}^{-1} \mathrm{H}_{2} \mathrm{O}\right)$.

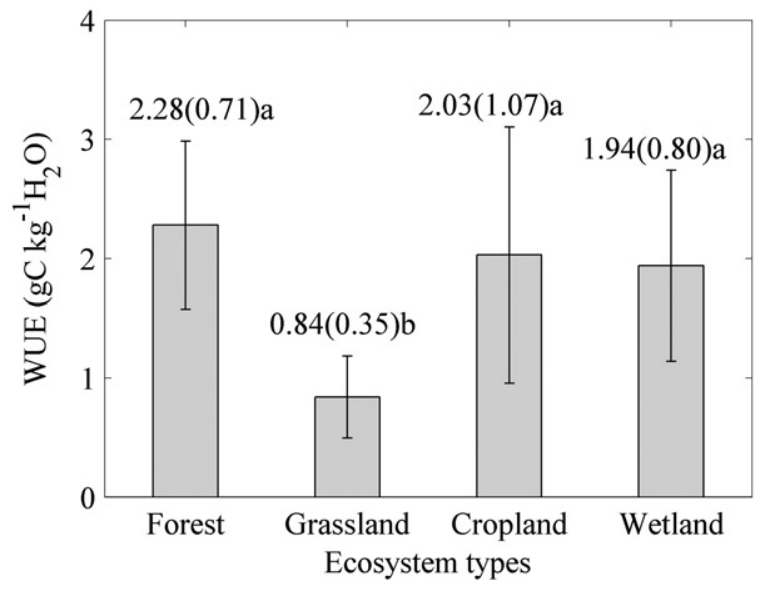

Fig. 2. Estimates of water use efficiency (WUE) in each ecosystem type. The text above each ecosystem type was the mean value of WUE, and the text in the bracket was the standard deviation of WUE for ecosystems in each ecosystem type. Different letters indicate significant differences among ecosystem types and regions based on a one-way analysis of variance $(\alpha=0.05)$. 


\subsection{Geographical spatial patterns of WUE}

WUE showed specific spatial patterns that varied with geographical factors, including latitude, longitude, and altitude (Fig. 3).

Among ecosystems within the same ecosystem type, the significant geographical spatial patterns of WUE only appeared in cropland ecosystems and wetland ecosystems (Fig. 3a and f). Among cropland ecosystems, WUE showed a significant decreasing trend with the increasing latitude (Fig. 3a). Among wetland ecosystems, the increasing altitude also led to a decreasing WUE (Fig. 3f).

Across ecosystem types, WUE exhibited obvious geographical spatial patterns (Fig. 3g-i), which differed from those among ecosystems within the same ecosystem type. WUE, not exhibiting a trend that appeared to be related to latitude (Fig. $3 g$ ), did not show a significant latitudinal pattern, while WUE did exhibit a longitudinal pattern, in which increasing longitude significantly enhanced WUE (Fig. 3h). In addition, WUE exhibited an obvious altitudinal pattern that reflected its vertical distribution (Fig. 3i). With the increasing altitude, WUE significantly decreased with an $R^{2}$ of 0.30 and a root mean square error (RMSE) of $0.76 \mathrm{gC} \mathrm{kg}^{-1} \mathrm{H}_{2} \mathrm{O}$ (Fig. 3i).

\subsection{The linkages between WUE and its elements}

The linkages between WUE and its elements (GPP and ET) were investigated to identify elements that directly affected the spatial variation of WUE (Fig. 4).

Among ecosystems within the same ecosystem type, WUE significantly correlated with GPP in some ecosystem types but did not show a significant correlation with ET (Fig. 4a-d). In addition, the significant correlation between WUE and GPP only appeared in cropland ecosystems and grassland ecosystems (Fig. 4a and c). Among cropland ecosystems and grassland ecosystems, WUE significantly linearly increased with the increasing GPP (Fig. 4a and c). Though WUE also exhibited an increasing trend with the increasing GPP among forest ecosystems and wetland ecosystems, their correlations were not significant in statistics (Fig. 4a and $\mathrm{c}$ ).

Across ecosystem types, the relationships between WUE and its elements distinctly differed between elements (Fig. $4 \mathrm{e}$ and f). The spatial pattern of GPP was highly positively correlated with that of WUE. With the increasing GPP, WUE exhibited a significant increasing trend in a logarithmical way, with an $R^{2}$ of 0.75 and an RMSE of $0.47 \mathrm{gC} \mathrm{kg}^{-1} \mathrm{H}_{2} \mathrm{O}$. However, though the correlation between ET and WUE was significant in statistics, ET only explained $15 \%$ of the spatial variation of WUE (Fig. 4f).

\subsection{Factors affecting the spatial variation of WUE}

The spatial pattern of WUE may result from the spatial variations of hydrothermal conditions. The effects of the spatial variations of climatic factors, including MAT, MAP, and MAR, on the spatial pattern of WUE were therefore investigated (Fig. 5).

Among ecosystems within the same ecosystem type, the significant effect of climatic factors on the spatial variation of WUE only occurred in cropland ecosystems and wetland ecosystems (Fig. 5a and f). Among cropland ecosystems, the increasing MAT made WUE increase linearly. However, among wetland ecosystems, MAR was the only factor found to affect the spatial variation of WUE. With the increasing MAR in spatial, WUE showed a significant decreasing trend (Fig. 5f).

Across ecosystem types, the spatial variation of MAT, MAP, and MAR all significantly influenced the spatial variation of WUE, but the responses of WUE to MAT, MAP, and MAR differed (Fig. 5g-i). The increasing MAT led to a linear increase in WUE, with an $R^{2}$ of 0.26 and
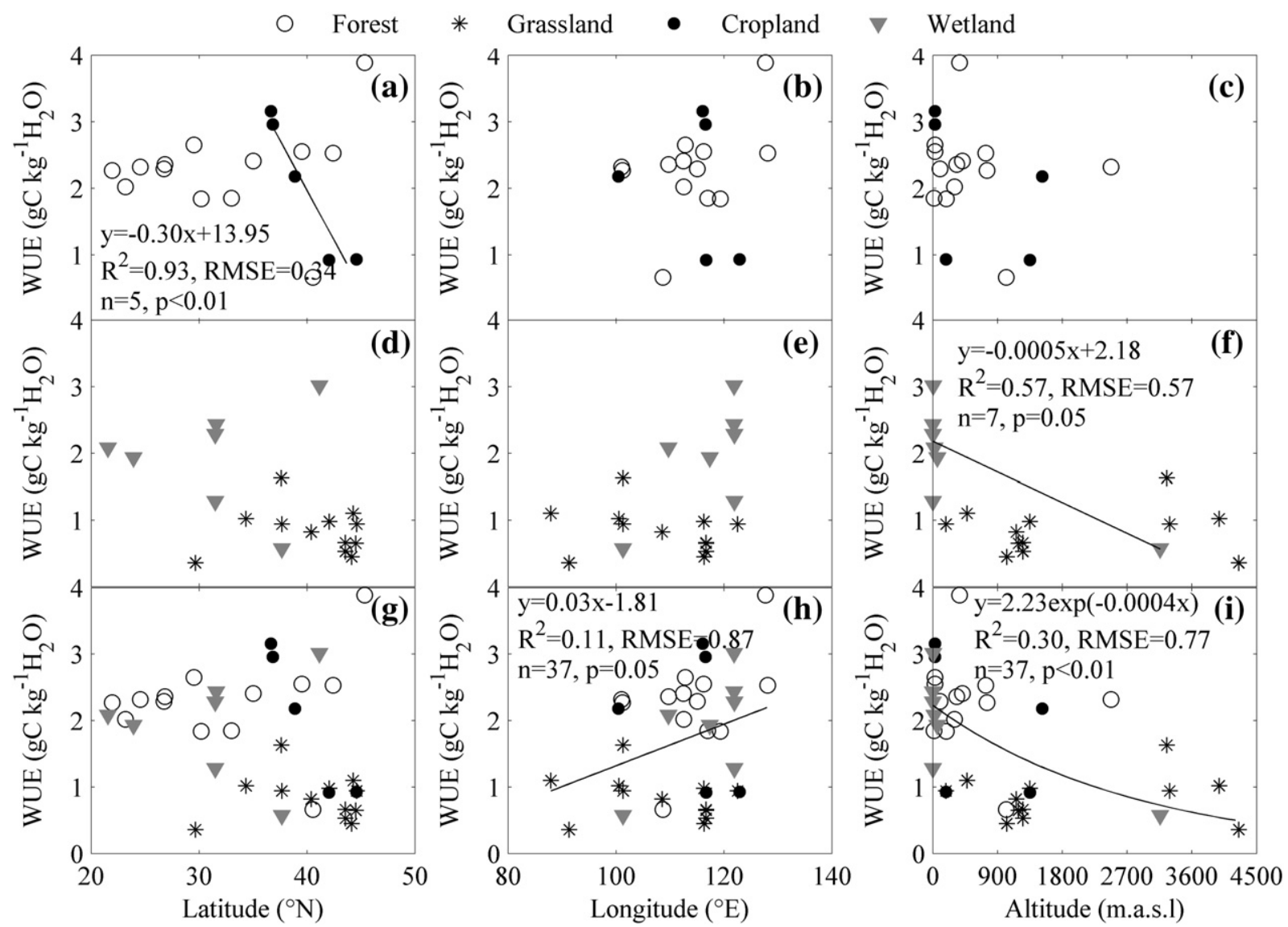

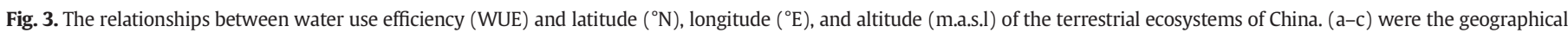
patterns of WUE among forests and croplands, while (d-f) were those among grasslands and wetlands. (g-i) were the geographical spatial patterns of WUE across ecosystem types. 




- Cropland $\nabla$ Wetland

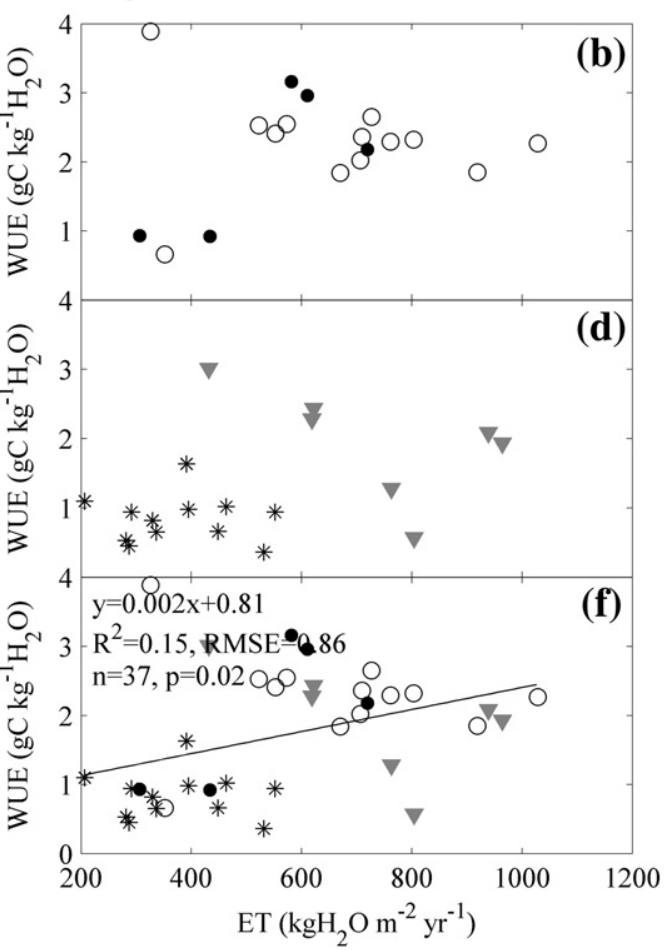

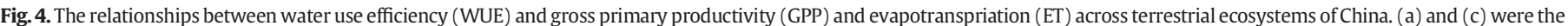

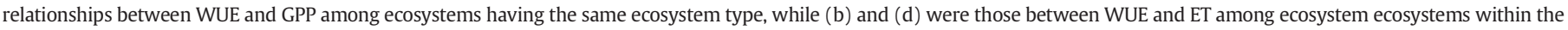
same ecosystem type. (e-f) were the relationships between WUE and GPP (e) and ET (f) across ecosystem types.

an RMSE of $0.79 \mathrm{gC} \mathrm{kg}^{-1} \mathrm{H}_{2} \mathrm{O}$ (Fig. $5 \mathrm{~g}$ ), while the increasing MAP enhanced WUE in a logarithmical way, with an $R^{2}$ of 0.24 and an RMSE of $0.80 \mathrm{gC} \mathrm{kg}^{-1} \mathrm{H}_{2} \mathrm{O}$ (Fig. 5h). However, the increasing MAR was associated with a significant decrease in WUE, with an $R^{2}$ of 0.40 and an RMSE of $0.72 \mathrm{gC} \mathrm{kg}^{-1} \mathrm{H}_{2} \mathrm{O}$ (Fig. 5i).

Furthermore, mean annual leaf area index (MLAI), which was an important biotic factor comprehensively reflecting the climatic variations, influenced that of WUE among terrestrial ecosystems of China (Fig. 6). Among cropland ecosystems and grassland ecosystems, the increasing MLAI both significantly enhanced WUE in spatial (Fig. 6a and b), while the correlations between WUE and MLAI among forest ecosystems and wetland ecosystems were not statistically significant (Fig. 6a and b). Across ecosystem types, the increasing MLAI led to a significant increase in WUE. With the increase in MLAI, WUE increased in a logarithmic fashion with an $R^{2}$ was 0.54 and the RMSE was $0.63 \mathrm{gC} \mathrm{kg}^{-1} \mathrm{H}_{2} \mathrm{O}$ (Fig. 6).

\section{Discussion}

\subsection{The vertical variation of WUE}

In this study, we found that WUE exhibited an obvious vertical variation across ecosystem types, which was showed as a decreasing trend with the increasing altitude (Fig. 3i). However, except its significant latitudinal pattern among cropland ecosystems and the obvious altitudinal pattern among wetland ecosystems, WUE showed no obvious geographical patterns among ecosystems within the same ecosystem type (Fig. 3a-f). In addition, in most cases, WUE did not significantly correlate with environmental factors within the same ecosystem type (Figs. 4a-f and 5a-d) but showed significant relationship with environmental factors across ecosystem types (Figs. $4 \mathrm{~g}-\mathrm{i}$ and $5 \mathrm{e}-\mathrm{f}$ ). Moreover, the variation in latitude, longitude, and altitude was accompanied with the spatial variation of climate, which eventually affected the spatial distribution of ecosystem types. For example, the variation of altitude reflected the distribution of ecosystem types (Fig. 3c and f). Forest ecosystems and cropland ecosystems mostly appeared in areas having the altitude lower than $2000 \mathrm{~m}$ (Fig. 3c), while grassland ecosystems primarily located in areas having the altitude higher than $1000 \mathrm{~m}$ (Fig. 3f). Therefore, the vertical variation of WUE primarily resulted from that of ecosystem types, which also reflected the difference in climate among regions.

\subsection{Direct factors describing the spatial variation of WUE}

After fully considering the vertical variation of WUE, we found that many factors, including MAT, MAP, and MLAI, affected the spatial variation of WUE, which was also found in previous studies (Beer et al., 2007, 2009; Hu et al., 2008; Yu et al., 2008; Xiao et al., 2013). Besides those factors, we also found that altitude and MAR affected the spatial variation of WUE (Figs. 3i and 5i), which was not found in previous studies.

Given to the complex interaction among factors, we explored the path analysis to reveal factors directly describing the spatial variation of WUE. Results suggest that two comprehensive variables, MLAI and altitude, directly affected the spatial variation of WUE. Based on MLAI and altitude, we constructed an equation describing the spatial variation of WUE (Eq. (1)), which explained $65 \%$ of spatial variation of WUE, with an RMSE of $0.55 \mathrm{gC} \mathrm{kg}^{-1} \mathrm{H}_{2} \mathrm{O}$. This equation provides an alternative approach for regional WUE and then carbon budget assessment.

WUE $=0.58 \log (\mathrm{MLAI})-0.0003$ Altitude +2.32 ,

$R^{2}=0.65$, RMSE $=0.55$

The effect of MLAI on the spatial variation of WUE reflected that of MAT and MAP. Previous studies suggest that the spatial variation of MAT and MAP strongly influenced that of GPP (Chapin et al., 2012; 


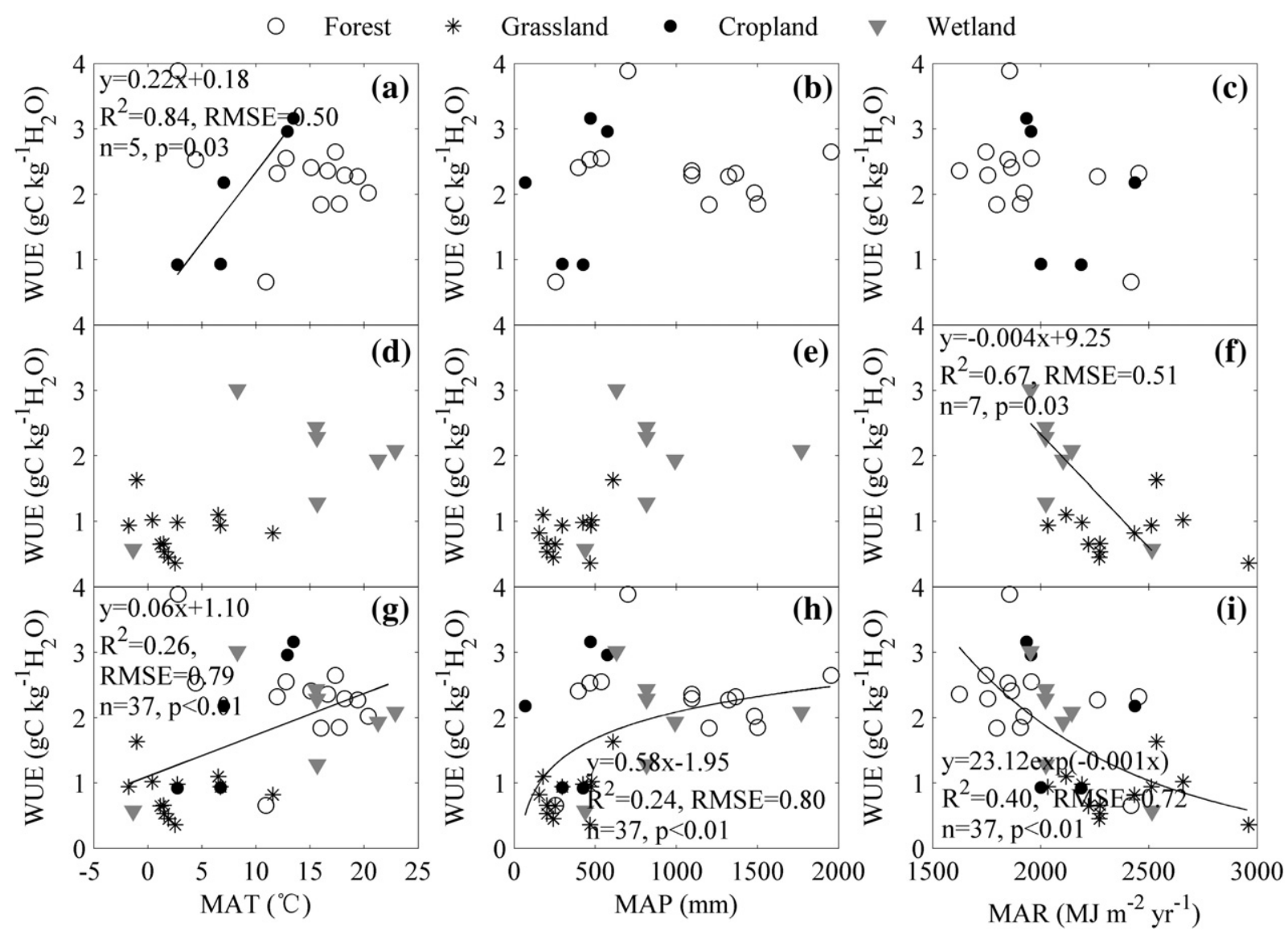

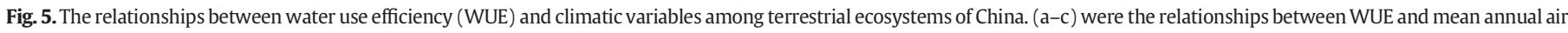

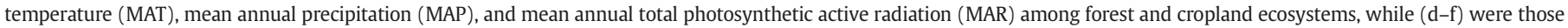
among grassland and wetland ecosystems and ( $\mathrm{g}-\mathrm{i}$ ) were those across ecosystem types.

Yu et al., 2013). In addition, the spatial pattern of GPP was closely related to that of MLAI (Supplementary Fig. 2). Therefore, the spatial variation of MLAI was related to that of MAT and MAP. Our data also suggest that MLAI highly correlated with MAT and MAP (Supplementary Fig. 3).

The effect of altitude on the spatial variation of WUE may reflect that of MAT and MAR. Previous study indicate that the increasing latitude was accompanied with an increasing MAR and a decreasing MAT (Korner, 2007). Our data also suggest that MAT and MAR closely correlated with the altitude (Supplementary Fig. 4).

\subsection{Mechanisms underlying the spatial variation of WUE}

ET is comprised by evaporation (E) and transpiration (T). Defined as the ratio of GPP to ET, WUE can therefore be divided into two parts: the ratio of GPP to $\mathrm{T}(\mathrm{GPP} / \mathrm{T})$ and $\mathrm{T} / \mathrm{ET}$, which are affected by different processes (Hu et al., 2008). GPP/T, reflecting the efficiency of plants in utilizing water to uptake carbon, is mainly affected by the adaption of plants to the environment. While T/ET, indicating the water allocation between physical and biological processes, is mainly influenced by LAI (Huxman et al., 2005; Hu et al., 2008).

The effects of MAT, MAP, and MLAI on the spatial variation of WUE may be achieved through the altering T/ET. With the increasing MAT and MAP, MLAI significantly increased (Supplementary Fig. 3). The increasing MLAI also led to an increase in T/ET (Wang et al., 2014). In addition, T/ET played an important role in shaping the spatial variation of WUE (Hu et al., 2008), which made the increasing MAT, MAP, and MLAI enhance WUE (Figs. 5g, h, and 6c).
However, we must admit that we were still uncertain about how MAR affected the spatial variation of WUE. Though MAR is an important climatic factor for forming productivity, MAR showed little relation with GPP in spatial (Supplementary Fig. 5a), which was also found in the previous study (Garbulsky et al., 2010). In addition, MAR may also reflect the variation of available energy, which may affect the spatial variation of ET, while our results suggest that ET was weakly correlated with MAR (Supplementary Figure. 5b) and WUE (Fig. 4f). Therefore, the effect of MAR on the spatial variation of WUE may not be achieved by altering GPP or ET but by altering another factor closely linked with MAR. Moreover, the increasing MAR was caused by the increasing altitude (Korner, 2007), which was also accompanied with the decreasing atmosphere pressure (Korner, 2007). The variation of atmosphere pressure directly affected that of $\mathrm{CO}_{2}$ partial pressure, which linked to the variation of GPP and WUE. Therefore, $\mathrm{CO}_{2}$ partial pressure may be the direct factor affecting the spatial variation of WUE, which should be the subject of future investigations.

Previous studies suggest that plants consume more water in producing per unit productivity when water is much abundant (Gebrekirstos et al., 2009; Diefendorf et al., 2010). This contradicts to our finding because of the following aspects. First, previous studies focused on the water utilization in plant while we had ecosystem water use efficiency as the target. Second, the variation of WUE used in this study reflected the comprehensive variation of plant community water utilization (GPP/T) and T/ET, while the latter played an important role in the spatial variation of WUE.

The complicated composition of ET also made the correlation between ET and WUE insignificant (Fig. 4b). Though T is closely linked with the variation of GPP (Steduto et al., 2007) thus WUE, E is also an 


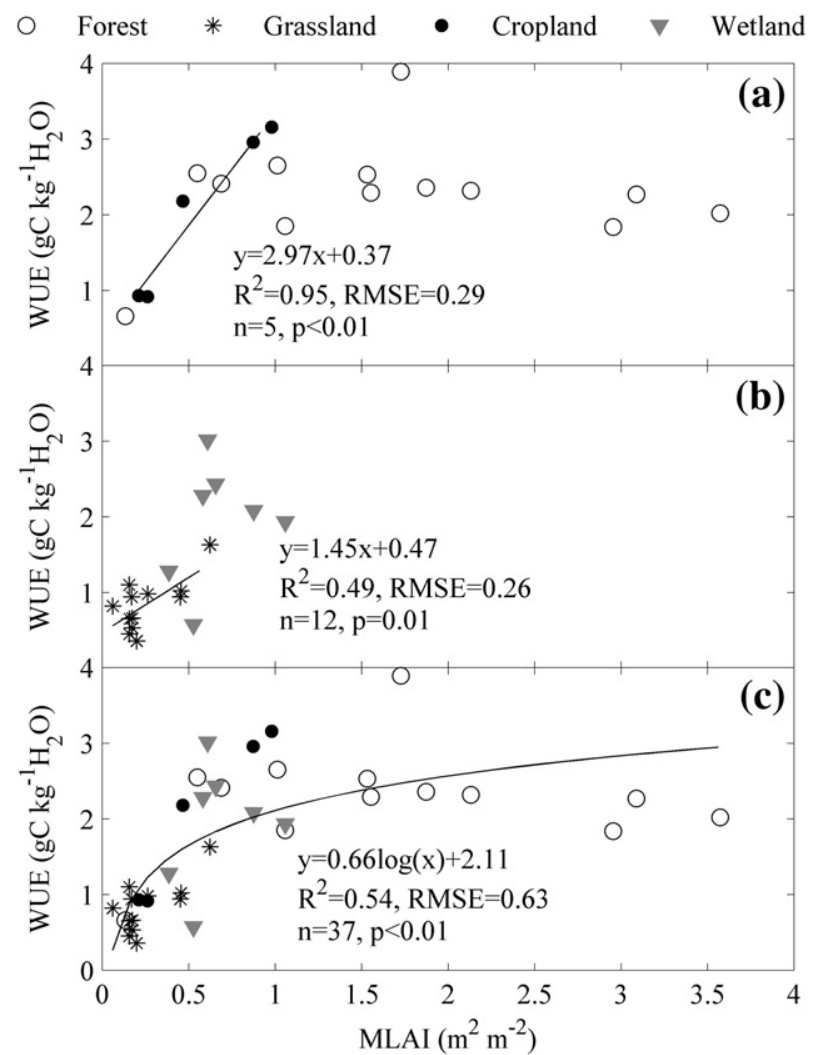

Fig. 6. The relationships between water use efficiency (WUE) and mean annual leaf area index (MLAI) among ecosystems in China. (a-b) were the relationships between WUE and MLAI among forest and cropland ecosystems (a) and among grassland and wetland ecosystems (b), while (c) was that across ecosystem types.

important part of ET, and the ratio of E to ET (E/ET) varied among ecosystems (Hu et al., 2009; Schlesinger and Jasechko, 2014; Wang et al., 2014; Zhu et al., 2015).

\section{Conclusions}

Based on ChinaFLUX measurements and published data in the literature, we built a dataset containing annual total GPP and ET data from 37 sites in China and analyzed the spatial variation of WUE. WUE decreased significantly with the increasing altitude, which resulted from the ecosystem type distribution as a result of the climatic gradient. After fully considering the vertical variation of WUE, we found that not only MAT, MAP, and MLAI but also MAR affected the spatial variation of WUE, while the spatial variation of WUE could be mostly depicted by the equation only containing MLAI and altitude. The effects of MAT and MAP on the spatial variation of WUE was achieved through altering MLAI, while the mechanism underlying the effect of MAR on the spatial variation of WUE was still unclear, which needs deeply investigations in the future.

\section{Acknowledgments}

This research was supported by the National Natural Science Foundation of China (31290221, 31420103917, and 41301043) National Key Research and Development Program (2010CB833504), the CAS Strategic Priority Research Program (XDA05050601), and Funding for talent young scientists of IGSNRR (2013RC203). Special thanks to data provider from the FLUXNET community especially ChinaFLUX and USCCC networks. We gratefully acknowledge the reviewers for spending their valuable time to provide constructive comments.

\section{Appendix A. Supplementary data}

Supplementary data to this article can be found online at http://dx. doi.org/10.1016/j.gloplacha.2015.03.003.

\section{References}

Aubinet, M., Grelle, A., Ibrom, A., Rannik, U., Moncrieff, J., Foken, T., Kowalski, A.S., Martin, P.H., Berbigier, P., Bernhofer, C., Clement, R., Elbers, J., Granier, A., Grunwald, T., Morgenstern, K., Pilegaard, K., Rebmann, C., Snijders, W., Valentini, R., Vesala, T., 2000. Estimates of the annual net carbon and water exchange of forests: the EUROFLUX methodology. Adv. Ecol. Res. 30, 113-175.

Baldocchi, D., Falge, E., Gu, L.H., Olson, R., Hollinger, D., Running, S., Anthoni, P., Bernhofer, C., Davis, K., Evans, R., Fuentes, J., Goldstein, A., Katul, G., Law, B., Lee, X.H., Malhi, Y., Meyers, T., Munger, W., Oechel, W.U.K.T.P., Pilegaard, K., Schmid, H.P., Valentini, R., Verma, S., Vesala, T., Wilson, K., Wofsy, S., 2001. FLUXNET: a new tool to study the temporal and spatial variability of ecosystem-scale carbon dioxide, water vapor, and energy flux densities. Bull. Am. Meteorol. Soc. 82 (11), 2415-2434.

Beer, C., Reichstein, M., Ciais, P., Farquhar, G.D., Papale, D., 2007. Mean annual GPP of Europe derived from its water balance. Geophys. Res. Lett. 34 (5), L05401.

Beer, C., Ciais, P., Reichstein, M., Baldocchi, D., Law, B.E., Papale, D., Soussana, J.F., Ammann, C., Buchmann, N., Frank, D., Gianelle, D., Janssens, I.A., Knohl, A., Kostner, B., Moors, E., Roupsard, O., Verbeeck, H., Vesala, T., Williams, C.A., Wohlfahrt, G., 2009. Temporal and among-site variability of inherent water use efficiency at the ecosystem level. Glob. Biogeochem. Cycles 23, GB2018.

Beer, C., Reichstein, M., Tomelleri, E., Ciais, P., Jung, M., Carvalhais, N., Rodenbeck, C., Arain, M.A., Baldocchi, D., Bonan, G.B. Bondeau, A. Cescatti, A. Lasslop, G., Lindroth, A. Lomas, M., Luyssaert, S., Margolis, H., Oleson, K.W., Roupsard, O., Veenendaal, E., Viovy, N., Williams, C., Woodward, F.I., Papale, D., 2010. Terrestrial gross carbon dioxide uptake: global distribution and covariation with climate. Science 329 (5993), 834-838.

Chapin, F.S., Matson, P.A., Vitousek, P.M., 2012. Principles of Terrestrial Ecosystem Ecology. Springer, New York, USA.

Diefendorf, A.F., Mueller, K.E., Wing S.L., Koch, P.L., Freeman, K.H., 2010. Global patterns in leaf $13 \mathrm{C}$ discrimination and implications for studies of past and future climate. Proc. Natl. Acad. Sci. 107 (13), 5738-5743.

Editorial Committee of Vegetation Map of China, 2007. Vegetation Map of the People's Republic of China (1:1000 000). Geology Publishing House, Beijing, China.

Falge, E., Baldocchi, D., Olson, R., Anthoni, P., Aubinet, M., Bernhofer, C., Burba, G., Ceulemans, G., Clement, R., Dolman, H., Granier, A., Gross, P., Grunwald, T., Hollinger, D., Jensen, N.O., Katul, G., Keronen, P., Kowalski, A., Lai, C.T., Law, B.E., Meyers, T., Moncrieff, J., Moors, E., Munger, J.W., Pilegaard, K., Rannik, U., Rebmann, C., Suyker, A., Tenhunen, J., Tu, K., Verma, S., Vesala, T., Wilson, K., Wofsy, S., 2001a. Gap filling strategies for long term energy flux data sets. Agric. For. Meteorol. 107 (1), 71-77.

Falge, E., Baldocchi, D., Olson, R., Anthoni, P., Aubinet, M., Bernhofer, C., Burba, G., Ceulemans, R., Clement, R., Dolman, H., Granier, A., Gross, P., Grunwald, T., Hollinger, D., Jensen, N.O., Katul, G., Keronen, P., Kowalski, A., Lai, C.T., Law, B.E., Meyers, T., Moncrieff, H., Moors, E., Munger, J.W., Pilegaard, K., Rannik, U., Rebmann, C., Suyker, A., Tenhunen, J., Tu, K., Verma, S., Vesala, T., Wilson, K., Wofsy, S., 2001b. Gap filling strategies for defensible annual sums of net ecosystem exchange. Agric. For. Meteorol. 107 (1), 43-69.

Finzi, A.C., Austin, A.T., Cleland, E.E., Frey, S.D., Houlton, B.Z., Wallenstein, M.D., 2011. Responses and feedbacks of coupled biogeochemical cycles to climate change: examples from terrestrial ecosystems. Front. Ecol. Environ. 9 (1), 61-67.

Gao, Y., Yu, G., Yan, H., Zhu, X., Li, S., Wang, Q., Zhang, J., Wang, Y., Li, Y., Zhao, L., Shi, P., 2014. A MODIS-based photosynthetic capacity model to estimate gross primary production in Northern China and the Tibetan Plateau. Remote Sens. Environ. 148, $108-118$.

Garbulsky, M.F., Peñuelas, J., Papale, D., Ardö, J., Goulden, M.L., Kiely, G., Richardson, A.D., Rotenberg, E., Veenendaal, E.M., Filella, I., 2010. Patterns and controls of the variability of radiation use efficiency and primary productivity across terrestrial ecosystems. Glob. Ecol. Biogeogr. 19 (2), 253-267.

Gebrekirstos, A., Worbes, M., Teketay, D., Fetene, M., Mitlöhner, R., 2009. Stable carbon isotope ratios in tree rings of co-occurring species from semi-arid tropics in Africa: patterns and climatic signals. Glob. Planet. Chang. 66 (3-4), 253-260.

Hossen, M.S., Mano, M., Miyata, A., Baten, M.A., Hiyama, T., 2012. Surface energy partitioning and evapotranspiration over a double-cropping paddy field in Bangladesh. Hydrol. Process. 26 (9), 1311-1320.

Hu, Z.M., Yu, G.R., Fu, Y.L., Sun, X.M., Li, Y.N., Shi, P.L., Wang Y.F., Zheng, Z.M., 2008. Effects of vegetation control on ecosystem water use efficiency within and among four grassland ecosystems in China. Glob. Chang. Biol. 14 (7), 1609-1619.

Hu, Z.M., Yu, G.R., Zhou, Y.L., Sun, X.M., Li, Y.N., Shi, P.L., Wang, Y.F., Song, X., Zheng, Z.M., Zhang, L., Li, S.G., 2009. Partitioning of evapotranspiration and its controls in four grassland ecosystems: application of a two-source model. Agric. For. Meteorol. 149 (9), 1410-1420

Huxman, T.E. Wilcox, B.P., Breshears, D.D., Scott, R.L., Snyder, K.A., Small, E.E., Hultine, K, Pockman, W.T., Jackson, R.B., 2005. Ecohydrological implications of woody plant encroachment. Ecology 86 (2), 308-319.

Ito, A., Inatomi, M., 2012. Water-use efficiency of the terrestrial biosphere: a model analysis focusing on interactions between the global carbon and water cycles. J. Hydrometeorol. 13 (2), 681-694.

Korner, C., 2007. The use of 'altitude' in ecological research. Trends Ecol. Evol. 22 (11), 569-574. 
Li, Z., Yu, G., Wen, X., Zhang, L., Ren, C., Fu, Y., 2005. Energy balance closure at ChinaFLUX sites. Sci. China. Ser. D Earth Sci. 48 (z1), 51-62.

Liu, M., He, H., Yu, G.R., Sun, X., Zhu, X., Zhang, L., Zhao, X., Wang, H., Shi, P., Han, S., 2010. Impacts of uncertainty in data processing on estimation of $\mathrm{CO}_{2}$ flux components. Chin. J. Appl. Ecol. 21 (9), 2389-2396 (in Chinese with English abstract).

Liu, Y., Liu, R., Chen, J.M., 2012. Retrospective retrieval of long-term consistent global leaf area index (1981-2011) from combined AVHRR and MODIS data. J. Geophys. Res. Biogeosci. 117 (G4), G04003.

Reichstein, M., Tenhunen, J.D., Roupsard, O., Ourcival, J.M., Rambal, S., Miglietta, F., Peressotti, A., Pecchiari, M., Tirone, G., Valentini, R., 2002. Severe drought effects on ecosystem $\mathrm{CO}_{2}$ and $\mathrm{H}_{2} \mathrm{O}$ fluxes at three Mediterranean evergreen sites: revision of current hypotheses? Glob. Chang. Biol. 8 (10), 999-1017.

Reichstein, M., Falge, E., Baldocchi, D., Papale, D., Aubinet, M., Berbigier, P., Bernhofer, C., Buchmann, N., Gilmanov, T., Granier, A., Grunwald, T., Havrankova, K., Ilvesniemi, H., Janous, D., Knohl, A., Laurila, T., Lohila, A., Loustau, D., Matteucci, G., Meyers, T., Miglietta, F., Ourcival, J.M., Pumpanen, J., Rambal, S., Rotenberg, E., Sanz, M., Tenhunen, J., Seufert, G., Vaccari, F., Vesala, T., Yakir, D., Valentini, R., 2005. On the separation of net ecosystem exchange into assimilation and ecosystem respiration: review and improved algorithm. Glob. Chang. Biol. 11 (9), 1424-1439.

Reichstein, M., Papale, D., Valentini, R., Aubinet, M., Bernhofer, C., Knohl, A., Laurila, T., Lindroth, A., Moors, E., Pilegaard, K., Seufert, G., 2007. Determinants of terrestrial ecosystem carbon balance inferred from European eddy covariance flux sites. Geophys. Res. Lett. 34 (1), L01402.

Schlesinger, W.H., Jasechko, S., 2014. Transpiration in the global water cycle. Agric. For. Meteorol. 189-190, 115-117.

Schlesinger, W.H., Cole, J.J., Finzi, A.C., Holland, E.A., 2011. Introduction to coupled biogeochemical cycles. Front. Ecol. Environ. 9 (1), 5-8.

Steduto, P., Hsiao, T., Fereres, E., 2007. On the conservative behavior of biomass water productivity. Irrig. Sci. 25 (3), 189-207.

Wang, Q., Liu, Y., He, N., Fang, H., Fu, Y., Yu, G., 2012. Demands and key scientific issues in the synthesis research on regional terrestrial ecosystem carbon budget in China. Prog. Geogr. 31 (1), 78-87 (in Chinese with English abstract).

Wang, L., Good, S.P., Caylor, K.K., 2014. Global synthesis of vegetation control on evapotranspiration partitioning. Geophys. Res. Lett. 41 (19), 6753-6757.

Webb, E.K., Pearman, G.L., Leuning, R., 1980. Correction of flux measurement for density effects due to heat and water vapor transfer. Q. J. R. Meteorol. Soc. 106 (1), 85-100.
Wu, G.X., Liu, Y.M., Wang, T.M., Wan, R.J., Liu, X., Li, W.P., Wang, Z.Z., Zhang, Q., Duan, A.M. Liang, X.Y., 2007. The influence of mechanical and thermal forcing by the Tibetan Plateau on Asian climate. J. Hydrometeorol. 8 (4), 770-789.

Xiao, J., Sun, G., Chen, J., Chen, H., Chen, S., Dong, G., Gao, S., Guo, H., Guo, J., Han, S., Kato, T., Li, Y., Lin, G., Lu, W., Ma, M., McNulty, S., Shao, C., Wang, X., Xie, X., Zhang, X., Zhang, Z. Zhao, B., Zhou, G., Zhou, J., 2013. Carbon fluxes, evapotranspiration, and water use efficiency of terrestrial ecosystems in China. Agric. For. Meteorol. 182-183, 76-90.

Xu, M.J., Wen, X.F., Wang, H.M., Zhang, W.J., Dai, X.O., Song, J., Wang, Y.D., Fu, X.L., Liu, Y.F., Sun, X.M., Yu, G.R., 2014. Effects of climatic factors and ecosystem responses on the inter-annual variability of evapotranspiration in a coniferous plantation in subtropical China. PLoS ONE 9 (1), e85593.

Yan, J., Liu, X., Tang, X., Yu, G., Zhang, L., Chen, Q., Li, K., 2013. Substantial amounts of carbon are sequestered during dry periods in an old-growth subtropical forest in South China. J. For. Res. 18 (1), 21-30.

Yu, G.-R, Wen, X-F., Sun, X-M., Tanner, B.D., Lee, X, Chen, J-Y., 2006. Overview of ChinaFLUX and evaluation of its eddy covariance measurement. Agric. For. Meteorol. 137 (3-4), 125-137.

Yu, G.R., Song, X., Wang, Q.F., Liu, Y.F., Guan, D.X., Yan, J.H., Sun, X.M., Zhang, L.M., Wen, X.F., 2008. Water-use efficiency of forest ecosystems in eastern China and its relations to climatic variables. New Phytol. 177 (4), 927-937.

Yu, G.-R., Zhu, X.-J., Fu, Y.-L., He, H.-L., Wang, Q.-F., Wen, X.-F., Li, X.-R., Zhang, L.-M., Zhang, L., Su, W., Li, S.-G., Sun, X.-M., Zhang, Y.-P., Zhang, J.-H., Yan, J.-H., Wang, H.-M., Zhou, G.-S., Jia, B.-R., Xiang, W.-H., Li, Y.-N., Zhao, L., Wang, Y.-F., Shi, P.-L., Chen, S.-P., Xin, X.-P., Zhao, F.-H., Wang, Y.-Y., Tong, C.-L., 2013. Spatial patterns and climate drivers of carbon fluxes in terrestrial ecosystems of China. Glob. Chang. Biol. 19 (3), 798-810.

Zhao, F.H., Yu, G.R., Li, S.G., Ren, C.Y., Sun, X.M., Mi, N., Li, J., Ouyang, Z., 2007. Canopy water use efficiency of winter wheat in the North China Plain. Agric. Water Manag. 93 (3), 99-108.

Zhu, X., He, H., Liu, M., Yu, G., Sun, X., Gao, Y., 2010. Spatio-temporal variation of photosynthetically active radiation in China in recent 50 years. J. Geogr. Sci. 20 (6), 803-817.

Zhu, X.-J., Yu, G.-R., Hu, Z.-M., Wang, Q.-F., He, H.-L., Yan, J.-H., Wang, H.-M., Zhang, J.-H., 2015. Spatiotemporal variations of T/ET (the ratio of transpiration to evapotranspiration) in three forests of Eastern China. Ecol. Indic. 52, 411-421. 